\title{
Impaired Growth Plate Chondrogenesis in Children with Chronic Illnesses
}

\author{
FRANCESCO DE LUCA \\ Section of Endocrinology and Diabetes, St. Christopher's Hospital for Children, Department of Pediatrics, Drexel University College of \\ Medicine, Philadelphia, Pennsylvania 19134
}

\begin{abstract}
In mammals, statural growth is primarily accomplished by endochondral ossification, which takes place at the growth plate. Growth plate chondrocyte proliferation, hypertrophy/ differentiation, apoptosis, and cartilage matrix synthesis all contribute to chondrogenesis or cartilage formation, a process tightly coupled to the simultaneous remodeling of the cartilage into bone at the metaphyseal border of the growth plate. Growth plate chondrogenesis is regulated by the complex interaction of molecular signals acting systemically as well locally within the growth plate. This network is often dysregulated during chronic illnesses, thus resulting in impaired growth plate chondrogenesis and, in turn, growth failure. The principal events responsible for altered growth plate chondrogenesis in chronic illness are inflammation, protein/calorie deprivation, uremia/ metabolic acidosis, glucocorticoids, and impaired GH/IGF-I axis. (Pediatr Res 59: 625-629, 2006)
\end{abstract}

$\mathrm{G}^{\mathrm{r}}$ rowth failure is a distinctive feature of many chronic diseases in children, such as CRF (1), inflammatory bowel diseases (2), rheumatoid arthritis (3), and cystic fibrosis (4). In mammals, poor statural growth results from disordered longitudinal bone growth, which in turn is primarily due to abnormal GP chondrogenesis (5). Chronic illnesses associated with growth retardation share a number of underlying mechanisms known to impair the function of the long bones' GP. These mechanisms are: 1) inflammation, 2) protein/calorie deprivation, 3) uremia/metabolic acidosis, 4) GH/IGF-I impaired action, and 5) GC (endogenous and exogenous).

This article reviews the experimental evidence supporting the association between these processes, impaired GP chondrogenesis, and longitudinal bone growth in chronic illnesses.

\section{GP CHONDROGENESIS AND LONGITUDINAL BONE GROWTH}

Longitudinal bone growth occurs at the GP (5). The cartilaginous GP is organized into three functionally and structurally distinct layers, the resting, the proliferative, and the hypertrophic zones (Fig. 1). In the resting zone, chondrocytes

Received October 31, 2005; accepted January 5, 2006.

Correspondence: Francesco De Luca, M.D., St. Christopher's Hospital for Children, Erie Avenue at Front Street, Philadelphia, PA 19134; e-mail: francesco.deluca@ drexel.edu

DOI: $10.1203 / 01 . p d r .0000214966 .60416 .1 b$ are irregularly arranged in a bed of cartilage matrix and rarely divide. Farther toward the metaphysis, in the proliferative zone, the chondrocytes show a flattened shape and are arranged in columns oriented parallel to the long axis of the bone. The proliferative chondrocytes farthest from the epiphysis stop replicating and instead enlarge to become hypertrophic chondrocytes. These terminally differentiated cells, which form a layer adjacent to the metaphysis termed the hypertrophic zone, eventually undergo apoptosis. Longitudinal bone growth occurs by endochondral ossification, a twostep process in which cartilage is first formed and then remodeled into bone. GP chondrocyte proliferation, hypertrophy, and extracellular matrix secretion lead to formation of new cartilage, chondrogenesis. After the terminally differentiated chondrocytes undergo apoptosis, the GP is invaded from the metaphysis by blood vessels and bone cell precursors that remodel the cartilage into bone. These two processes, chondrogenesis and ossification, are tightly coupled so that the width of the GP remains relatively constant while new bone is formed at the junction of the GP and the metaphyseal bone. The rates of GP chondrogenesis and, in turn, of longitudinal bone growth are regulated by multiple systemic (endocrine) factors (Fig. 2A). In addition, the underlying cellular processes of proliferation, differentiation, angiogenesis, and ossification appear to be regulated by a network of local (paracrine) factors, expressed in the GP (Fig. 2B).

\section{INFLAMMATION}

Juvenile rheumatoid arthritis (JRA) is a chronic inflammatory disease often associated with growth failure. Serum and synovial levels of IL-6, a major mediator of inflammation, are significantly elevated in children with JRA (6). In a recent study, it was found that transgenic mice overexpressing IL-6 experienced a stunted growth rate that led to a $50-70 \%$ smaller size when compared with age-matched littermates (7). Neutralization of IL-6 activity by a MAb produced a partial improvement of the animals' growth rate. IL-6 transgenic

Abbreviations: CRF, chronic renal failure; GC, glucocorticoids; GP, growth plate; IGF-BP, insulin-like growth factor-binding protein 


\section{EPIPHYSIS}

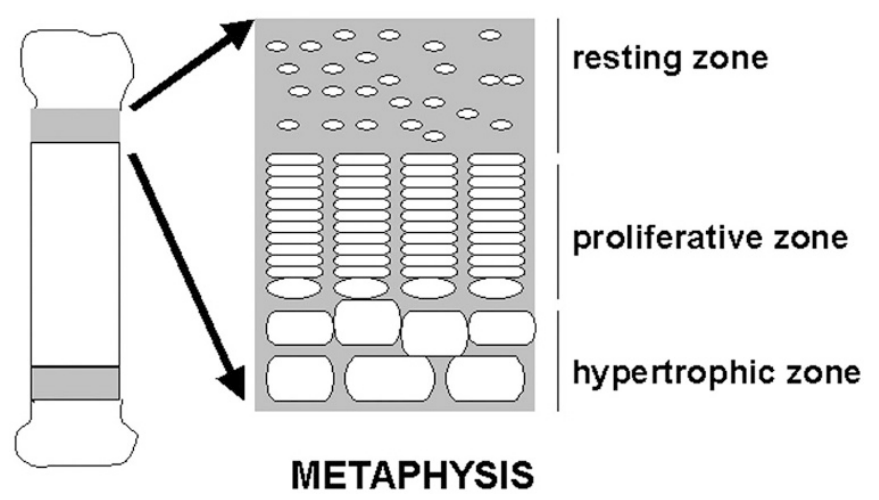

Figure 1. Histology of the GP.

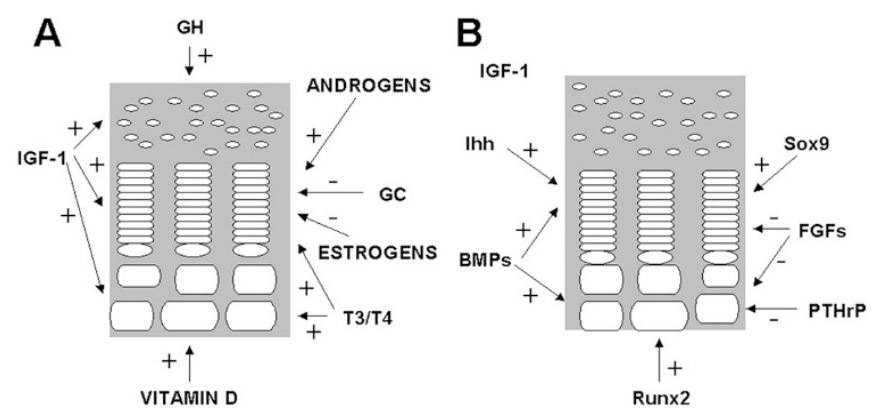

Figure 2. (A) Endocrine regulation of GP chondrogenesis. (B) Paracrine regulation of GP chondrogenesis. The arrow indicates on which GP zone systemic $(A)$ or locally expressed $(B)$ growth factors act directly, by stimulating (+) or by inhibiting (-) chondrocyte proliferation (in the GP resting and proliferative zones) or chondrocyte differentiation/hypertrophy (in the GP hypertrophic zone). IGF-I acts both as an endocrine and a paracrine growth factor. T3/T4, triiodothyronine//thyroxine; $F G F$, fibroblast growth factors; $B M P$, bone morphogenetic proteins; Ihh, Indian hedgehog; Sox9, sex determining region Y-box 9; Runx2, runt-related transcription factor 2; PTHrP, PTH-related protein.

mice were also found with reduced circulating levels of IGF-I (which promotes GP chondrogenesis acting as an endocrine as well as a paracrine factor) and normal levels of GH. In the same study, similarly reduced IGF-I levels were found in 21 children with JRA, with serum IGF-I levels being negatively correlated with IL-6 levels. Other pro-inflammatory cytokines, like IL-1 and tumor necrosis factor- $\alpha$ (TNF- $\alpha$ ), are also significantly elevated in chronic inflammatory illnesses such as JRA (8) or inflammatory bowel diseases (IBD) (9). In cultured whole rat metatarsal bones, high concentrations of both IL-1 and TNF- $\alpha$ impaired metatarsal longitudinal bone growth, decreased GP chondrocyte proliferation, and increased chondrocyte apoptosis (10). In contrast, IL-6 did not affect longitudinal bone growth. In another study, IL-1 affected proliferation of cultured rat costochondral chondrocytes, whereas IL-6 had no effect (11) All these studies suggest that the major inflammatory cytokines (IL-6, IL-1, and TNF- $\alpha$ ) inhibit GP chondrogenesis and longitudinal bone growth either directly at the GP (IL-1 and TNF- $\alpha$ ) or by reducing the systemic effects of IGF-I. Children with inflammatory bowel disease (more Crohn's disease than ulcerative colitis) often present with growth failure. At diagnosis, ap- proximately $90 \%$ of children with Crohn's have short stature (12), which persists in $30-40 \%$ of these children. In an experimental model of Crohn's disease (trinitrobenzene sulfonic acid-induced colitis) in rats, it has been demonstrated that inflammation independently inhibits linear growth (13). In these animals, immunoneutralization of IL-6 normalized serum IGF-I levels and linear growth. On the other hand, immunoneutralization of another mediator of inflammation, TNF- $\alpha$, induced a similarly stimulatory effect on the rats' growth without modifying their serum IGF-I levels. These findings would suggest that inflammatory cytokines may inhibit growth through multiple mechanisms (IGF-I and nonIGF-I mediated). In another study, experimental colitis induced in rats resulted in an abnormal GP morphology, with an increase of the resting zone's and reduction of both the proliferative and hypertrophic zone height (14).

\section{PROTEIN/CALORIE DEPRIVATION}

Protein/calorie deprivation (either due to malnutrition or malabsorption) is known to inhibit longitudinal bone growth $(15,16)$. Simmons et al. (17) first reported growth velocity in children treated with maintenance hemodialysis that was comparable to those with intact renal function when calories were supplemented to $70 \%$ of the recommended dietary allowance (RDA). Betts and Magrath (18) found a correlation between growth velocity and energy intake in children with CRF and concluded that diminished linear growth would occur when energy intake was $<80 \%$ of the RDA.

Experimental evidence indicates that malnutrition affects the systemic GH-IGF-I system. In rats, fasting diminishes both GH production (19) and hepatic GH sensitivity. The latter is associated with reduced hepatic GH receptor mRNA, GH binding, IGF-I mRNA, and circulating IGF-I (20-24). In humans, fasting induces increased circulating GH levels (25) and decreased IGF-I and GH binding protein levels (26). With respect to the effects of fasting on the GP, a 3-d fast in rats reduced the animals' growth rate to $30 \%$ of that of control animals, with a dramatic reduction of their overall GP height and with an apparent decrease of the chondrocyte number and volume in all the GP zones (27). In another study, rabbits fasted for $2 \mathrm{~d}$ exhibited decreased tibial growth velocity and GP width. In the fasted animals, serum IGF-I levels and hepatic IGF-I mRNA were decreased despite increased GH levels, suggesting hepatic resistance to GH (28).

\section{UREMIA/METABOLIC ACIDOSIS}

Growth retardation is a major manifestation of CRF in children. The uremic rat model has been extensively used to investigate growth impairment in CRF. In uremic rats, the height of the GP has been found to be greater $(29,30)$, equal $(31,32)$, or smaller $(33,34)$ than control animals. Some evidence indicates that GP morphology may vary according to the degree of secondary hyperparathyroidism. Sanchez et al. (34) have reported that, compared with control animals, the height of the GP cartilage of the proximal tibia of uremic rats remained unchanged in animals with mild hyperparathyroidism, but was markedly decreased in those with severe hyperparathyroidism. In contrast, increased growth cartilage and 
hypertrophic zone heights were observed in uremic rats with hypercalcemia, hypophosphatemia, and depressed serum PTH levels induced by calcium supplementation (32). Another study suggests that the height of the GP may depend on the severity and duration of renal failure, with a positive correlation between the degree of renal failure and the height of GP cartilage (30). Thus, only the animals with severe renal insufficiency exhibit an increased size of their GP. In rats with a milder degree of renal insufficiency, the size of the GP as well as the longitudinal bone growth rate may not be different from control. A consistent finding is that the increased GP height in uremic rats mainly results from an expansion of the GP hypertrophic zone (29), likely due to a prolonged duration of the hypertrophic phase. In addition to the expansion of the GP hypertrophic zone, the disorganized chondrocyte columns in the proliferative zone also suggests an overall disturbed GP chondrogenesis in uremic rats (29). A decreased expression of GH receptor protein (32) and IGF-I mRNA (35) in the proliferative zone of uremic rat GP are supportive of reduced chondrocyte proliferation. In nephrectomized rats fed a high calcium diet (which induces biochemical changes consistent with adynamic osteodystrophy), linear growth and tibial length were reduced, with the heights of the whole GP and of the GP hypertrophic zone significantly increased (36). Such morphologic changes were associated with a diminished chondroclastic/osteoclastic activity (decreased TRAP staining and MMP-9 mRNA expression), likely responsible for reduced cartilage degradation and resorption. Chronic metabolic acidosis, which is typically seen in renal diseases such as renal failure and renal tubular acidosis, is associated with growth retardation. Experimental studies have shown that metabolic acidosis decreases pulsatile GH secretion and reduces serum IGF-I levels (37). In addition, it has been shown that animals with severe metabolic acidosis exhibit reduced expression of chondrocyte IGF-I mRNA in the epiphyseal GP (38) and the lack of response to exogenous GH administration (39). Rats made acidotic by administration of ammonium chloride for $14 \mathrm{~d}$ and compared with pair-fed control rats exhibited a reduced longitudinal growth rate and a thinner GP (40). The decreased height of the GP was mainly due to a reduced height of the hypertrophic zone and, to a lesser degree, of the proliferative zone. In an in vitro study, murine mandibular condyles cultured for $3 \mathrm{~d}$ in acidic conditions ( $\mathrm{pH}$ 7.15) grew significantly less than control bones cultured in neutral conditions (41). In addition, acidosis down-regulated cartilage matrix proteoglycan and collagen II synthesis, and the expression of IGF-I, IGF-I receptor, and PTH receptor in the GP.

\section{GLUCOCORTICOIDS}

GC are widely used as anti-inflammatory and immunosuppressive drugs in children with chronic diseases. Long-term, high-dose GC treatment often leads to growth failure, which in mammals reflects impaired longitudinal bone growth (42).

To understand the mechanisms underlying GC-mediated growth failure, several investigators have focused their attention on the systemic and local effects of GC on the GP, the site where longitudinal bone growth takes place.
Systemic administration of GC in mice causes reduced whole GP width and tibial length, and growth retardation $(43,44)$. Similar results have been observed in rats $(45)$ and in rabbits (46). Such effects on the GP width are likely due to both a decreased number of proliferative chondrocytes $(43,47)$ as well as increased apoptosis of hypertrophic chondrocytes $(43,48,49)$. The apoptotic effect of GC in the GP is also confirmed by the observed increased expression of apoptotic proteins, caspase-3 (49) and Bax (50), and decreased expression of Bcl-2 and Bcl-x $(49,50)$ anti-apoptotic proteins. Regarding the molecular mechanisms underlying chondrocyte decreased proliferation and increased apoptosis, short-term systemic administration of GC in rodents decreases IGF-I expression in the GP $(43,51)$, whereas long-term treatment (1 mo) increases it (52). Growth-suppressive doses of dexamethasone given to rabbits increase GH receptor mRNA expression in the GP.

The suppressive effects of GC on GP chondrogenesis and longitudinal bone growth may be indirect (mediated by other systemic growth factors) and/or direct (mediated by the activation of the GC receptor in the GP) $(45,52,53)$. A direct effect of GC in the GP has been shown by a study in which local infusion of dexamethasone into a rabbit tibial GP caused a decreased growth rate of the treated tibia compared with the contralateral untreated one (54). To support this finding, observations in cultured chondrogenic cell line (55) and primary GP chondrocytes (56) have shown a suppressive effect of dexamethasone on cell proliferation. In addition, GC suppress $\mathrm{GH}$ receptor expression in cultured rat GP chondrocytes, whereas type-1 IGF receptor expression is not affected (56). In contrast, GC induces type-1 IGF receptor expression in porcine chondrocytes (57).

In conclusion, a large body of data consistently indicates that GC suppress statural growth by inhibiting GP chondrogenesis. In contrast, conflicting experimental evidence exists on the molecular mechanisms underlying the GC-mediated suppression of GP function.

\section{GH/IGF-I AXIS}

As discussed so far, most of the mechanisms responsible for growth retardation associated with chronic illnesses disturb the GH/IGF-I action on GP chondrocytes.

The effects of GH on the GP are in part mediated by the systemic effects of IGF-I. On the other hand, local GH injection in a tibial GP stimulates the ipsilateral tibial growth rate, without affecting the contralateral one (58). In cultured GP chondrocytes, GH induces resting zone chondrocyte proliferation and IGF-I secretion (59), which induces expansion of proliferating chondrocytes acting as a autocrine/paracrine factor. In support of a direct effect of GH on the GP, GH receptor has been demonstrated on chondrocytes in rabbit (60), rat (61), and human GP (62).

The possibility that GH has IGF-I-independent effects on longitudinal bone growth has long been debated. A recent study has shown that, in mice with targeted deletion of IGF-I, tibial growth rate was reduced by $35 \%$, whereas it was reduced by $65 \%$ in GH receptor null mice (63). The IGF-I null mice showed a GP with a significantly enlarged resting zone, 
a normal GP proliferative zone, and a reduced hypertrophic zones. In contrast, GH receptor null mice exhibit all GP zone significantly narrowed.

GH receptor null mice demonstrate attenuation of both numbers and size of GP chondrocytes, whereas IGF-I null mice exhibit only reduced chondrocyte size. The fact that the resting zone is enlarged and chondrocyte proliferation normal in the GP of IGF-I null mice supports the view that GH enhances chondrocyte generation and proliferation independent of IGF-I. Further support of an IGF-I-independent effect of $\mathrm{GH}$ on longitudinal bone growth derives from the increased width of the GP resting zone in IGF-I null mice injected with GH (64).

Additional experimental evidence suggests that $\mathrm{GH}$ acts in the GP by inducing resting cells to enter the proliferative cycle (65), whereas IGF-I stimulates GP chondrocyte proliferation and hypertrophy (64).

Abnormalities of the GH-IGF-I axis are thought to be one of the main mechanisms underlying growth failure in children with chronic diseases. Evidence indicates that a state of GH resistance, rather than GH deficiency, typically occurs in chronic illness. Children with cystic fibrosis $(66,67)$, chronic bowel inflammatory diseases $(68,69)$, or JRA (70) exhibit normal GH secretory pattern and low IGF-I and IGFBP-3 levels. In children with CRF, serum GH levels are normal or elevated $(71,72)$. Tonshoff et al. (73) have shown downregulation of hepatic $\mathrm{GH}$ receptor gene expression in uremic animals. In addition, circulating GH binding protein levels were found to be decreased in children and adults with CRF (74). In concordance with these findings, a reduced (nutritionindependent) GH receptor mRNA level has been described in uremic rats $(73,75)$. With respect to circulating IGF-I levels, they tend to be normal in children with preterminal CRF (76), whereas they are slightly decreased in end-stage renal disease (77). To explain the latter finding, it has been hypothesized that the inhibitory effect on IGF activity may be due to an excess of high-affinity IGFBP, especially IGFBP-1, $-2,-4$, and $-6(78,79)$.

\section{CONCLUSIONS}

Growth failure in chronic illness is primarily due to impaired longitudinal bone growth. The rate of growth elonga-

Table 1. Underlying mechanisms of growth retardation in chronic illnesses and their effects on the cellular processes characterizing GP chondrogenesis and ossification

\begin{tabular}{|c|c|c|c|c|}
\hline & \multicolumn{4}{|c|}{ Chondrogenesis } \\
\hline & Proliferation & Hypertrophy & Apoptosis & Ossification \\
\hline IL-6 & $(-)^{*}$ & $(-)^{*}$ & & \\
\hline IL- 1, TNF- $\alpha$ & - & & + & \\
\hline $\begin{array}{l}\text { Fasting protein/ } \\
\text { calorie deprivation }\end{array}$ & $(\text { - })^{* \dagger}$ & $($ (一)* & & \\
\hline Uremia & $(-)^{* \dagger}$ & $(-)^{*}$ & & - \\
\hline Metabolic acidosis & $(-)^{* \dagger}$ & $(-)^{*}$ & & \\
\hline GC & - & & + & \\
\hline & $(-)^{* \dagger}$ & $(-)^{*}$ & & \\
\hline
\end{tabular}

-, Inhibition; + , stimulation. When - or + are in parentheses, the effect is indirect, mediated by IGF-I $(*)$ and/or GH $(\dagger)$. tion depends on the rate of GP chondrogenesis, which is regulated by the interaction of multiple endocrine and paracrine signals. Processes such as malnutrition, acidosis, and uremia, and molecules like inflammatory cytokines and GC impaired the cellular events of chondrogenesis, acting systemically and/or locally at the GP (Table 1). Such detrimental effect on GP chondrogenesis is often, but not always, due to a state of relative GH resistance and decreased IGF-I bioactivity, characterized by reduced GH receptor and IGF-I expression and altered expression of IGFBPs. Further studies are needed to elucidate the causative role of other growth factors expressed in the GP in the growth failure associated with chronic diseases.

\section{REFERENCES}

1. Kuizon BD, Salusky IB 1999 Growth retardation in children with chronic renal failure. J Bone Miner Res 14:1680-1690

2. Ballinger A 2002 Fundamental mechanisms of growth failure in inflammatory bowel disease. Horm Res 58:7-10

3. Simon D, Lucidarme N, Prieur AM, Ruiz JC, Czernichow P 2002 Treatment of growth failure in juvenile chronic arthritis. Horm Res 58:28-32

4. Hardin DS 2002 Growth problems and growth hormone treatment in children with cystic fibrosis. J Pediatr Endocrinol Metab 15:731-735

5. Nilsson O, Marino R, De Luca F, Phillip M, Baron J 2005 Endocrine regulation of the growth plate. Horm Res 64:157-165

6. Mangge H, Kenzian H, Gallistl S, Neuwirth G, Liebmann P, Kaulfersch W, Beaufort F, Muntean W, Schauenstein K 1995 Serum cytokines in juvenile rheumatoid arthritis. Correlation with conventional inflammation parameters and clinical subtypes. Arthritis Rheum 38:211-220

7. De Benedetti F, Alonzi T, Moretta A, Lazzaro D, Costa P, Poli V, Martini A, Ciliberto G, Fattori E 1997 Interleukin 6 causes growth impairment in transgenic mice through a decrease in insulin-like growth factor-I. J Clin Invest 99:643-650

8. Ji H, Pettit A, Ohmura K, Ortiz-Lopez A, Duchatelle V, Degott C, Gravallese E, Mathis D, Benoist C 2002 Critical roles for interleukin 1 and tumor necrosis factor alpha in antibody-induced arthritis. J Exp Med 196:77-85

9. Funakoshi K, Sugimura K, Anezaki K, Bannai H, Ishizuka K, Asakura H 1998 Spectrum of cytokine gene expression in intestinal mucosal lesions of Crohn's disease and ulcerative colitis. Digestion 59:73-78

10. Martensson K, Chrysis D, Savendahl L 2004 Interleukin 1 and TNF- $\alpha$ act in synergy to inhibit longitudinal growth in fetal rat metatarsal bones. J Bone Miner Res 19:1805-1812

11. Horan J, Dean DD, Kieswetter K, Schwartz Z, Boyan BD 1996 Evidence that interleukin-1, but not interleukin-6, affects costochondral chondrocyte proliferation, differentiation, and matrix synthesis through an autocrine pathway. J Bone Miner Res 11:1119-1129

12. Kanof ME, Lake AM, Bayless TM 1988 Decreased height velocity in children and adolescents before the diagnosis of Crohn's disease. Gastroenterology 95:1523-1527

13. Ballinger AB, Azooz O, El-Haj T, Poole S, Farthing MJ 2000 Growth failure occurs through a decrease in insulin-like growth factor 1 which is independent of undernutrition in a rat model of colitis. Gut 46:694-700

14. Koniaris SG, Fisher SE, Rubin CT, Chawla A 1997 Experimental colitis impairs linear bone growth independent of nutritional factors. J Pediatr Gastroenterol Nutr 25:137-141

15. Price DA, Wit JM, Van Buul-Offers S, Korteland-Van Male AM, Van RooyenWehmeijer AK, Hoogerbrugge C, Van Den Brande JL 1979 Serum somatomedin activity and cartilage metabolism in acutely fasted, chronically malnourished, and refed rats. Endocrinology 105:851-861

16. Allen LH 1995 Malnutrition and human function: a comparison of conclusions from the INCAP and nutrition CRSP studies. J Nutr 125:1119S-1126S

17. Simmons JM, Wilson CJ, Potter DE, Holliday MA 1971 Relation of calorie deficiency to growth failure in children on hemodialysis and the growth response to calorie supplementation. N Engl J Med 285:653-656

18. Betts PR, Magrath G 1974 Growth pattern and dietary intake of children with chronic renal insufficiency. BMJ 2:189-193

19. Tannenbaum GS, Rorstad O, Brazeau P 1979 Effects of prolonged food deprivation on the ultradian growth hormone rhythm and immunoreactive somatostatin tissue levels in the rats. Endocrinology 104:1733-1738

20. Maes M, Underwood LE, Ketelslegers JM 1983 Plasma somatomedin-C in fasted and refed rats: close relationship with changes in liver somatogenic but not lactogenic binding sites. J Endocrinol 97:243-252

21. Straus DS, Takemoto CD 1990 Effects of fasting on insulin-like growth-factor-1 (IGF-I) and growth hormone receptor mRNA levels and IGF-1 gene transcription in rat liver. Mol Endocrinol 4:91-100

22. Mulumba N, Massa G, Ketelslegers JM, Maes M 1991 Ontogeny and nutritional regulation of the serum growth-hormone-binding protein in the rat. Acta Endocrinol (Copenh) 125:409-415

23. Lowe WL Jr, Adamo M, Werner H, Roberts CT Jr, LeRoith D 1989 Regulation by fasting of rat insulin-like growth factor I and its receptor. Effects on gene expression and binding. J Clin Invest 84:619-626 
24. Bornfeldt KE, Arnqvist HJ, Enberg B, Mathews LS, Norstedt G 1989 Regulation of insulin-like growth factor-1 and growth hormone receptor gene expression by diabetes and nutritional state in rat tissues. J Endocrinol 122:651-656

25. Ho KY, Veldhuis JD, Johnson ML, Furlanetto R, Evans WS, Alberti KG, Thorner MO 1988 Fasting enhances growth hormone secretion and amplifies the complex rhythms of growth hormone secretion in man. J Clin Invest 81:968-975

26. Counts DR, Gwirtsman H, Carlsson LM, Lesem M, Cutler GB 1992 The effect of anorexia nervosa and refeeding on growth hormone-binding protein, the insulin-like growth factors (IGFs) and the IGF-binding proteins. J Clin Endocrinol Metab 75:762-767

27. Farnum CE, Lee AO, O'Hara K, Wilsman NJ 2003 Effect of short-term fasting on bone elongation rates: an analysis of catch-up growth in young male rats. Pediatr Res 53:33-41

28. Heinrichs C, Colli M, Yanovski JA, Laue L, Gerstl NA, Kramer AD, Uyeda JA, Baron J 1997 Effects of fasting on the growth plate: systemic and local mechanisms. Endocrinology 138:5359-5365

29. Cobo A, Carbajo E, Santos F, Garcia E, Lopez JM 1996 Morphometry of uremic growth plate. Miner Electrolyte Metab 22:192-195

30. Fernandez-Fuente M, Santos F, Carbajo-Perez E, Rodriguez J, Weruaga A, Amil B, Molinos I, Garcia E 2004 Growth plate height of uremic rats is influenced by severity and duration of renal failure. Pediatr Nephrol 19:187-192

31. Sanchez CP, He YZ 2003 Effects of thyroparathyroidectomy, exogenous calcium, and short-term calcitriol therapy on the growth plate in renal failure. J Am Soc Nephrol 14:148-158

32. Sanchez CP, He YZ 2004 Growth hormone therapy in calcium-loaded rats with renal failure. Endocrinology 145:3375-3385

33. Urena P, Ferreira A, Morieux C, Drueke T, de Vernejoul MC 1996 PTH/PTHrP receptor mRNA is down-regulated in epiphyseal cartilage growth plate of uraemic rats. Nephrol Dial Transplant 11:2008-2016

34. Sanchez CP, Salusky IB, Kuizon BD, Abdella P, Juppner H, Goodman WG 1998 Growth of long bones in renal failure: roles of hyperparathyroidism, growth hormone, and calcitriol. Kidney Int 54:1879-1887

35. Hanna JD, Santos F, Foreman JW, Chan JC, Han VK 1995 Insulin-like growth factor-I gene expression in the tibial epiphyseal growth plate of growth hormonetreated uremic rats. Kidney Int 47:1374-1382

36. Sanchez CP, Kuizon BD, Abdella PA, Juppner H, Salusky IB, Goodman WG 2000 Impaired growth, delayed ossification, and reduced osteoclastic activity in the growth plate of calcium-supplemented rats with renal failure. Endocrinology 141:1536-1544

37. Kuemmerle N, Krieg RJ, Latta K, Challa A, Hanna JD, Chan JC 1997 Growth hormone and insulin-like growth factor in non-uremic acidosis and uremic acidosis. Kidney Int 58:S102-S105

38. Green J, Maor G 2000 Effect of metabolic acidosis on the growth hormone/IGF-I endocrine axis in skeletal growth centers. Kidney Int 57:2258-2267

39. Maniar S, Kleinknecht C, Zhou X, Motel V, Yvert JP, Dechaux M 1996 Growth hormone action is blunted by acidosis in experimental uremia or acid load. Clin Nephrol 46:72-76

40. Carbajo E, Lopez JM, Santos F, Ordonez FA, Nino P, Rodriguez J 2001 Histologic and dynamic changes induced by chronic metabolic acidosis in the rat growth plate. J Am Soc Nephrol 12:1228-1234

41. Green J, Goldberg R, Maor G 2003 PTH ameliorates acidosis-induced adverse effects in skeletal growth centers: the PTH-IGF-1 axis. Kidney Int 63:487-500

42. Allen DB 1996 Growth suppression by glucocorticoid therapy. Endocrinol Metab Clin North Am 25:699-717

43. Smink JJ, Gresnigt MG, Hamers N, Koedam JA, Berger R, van Buul-Offers SC 2003 Short-term glucocorticoid treatment of prepubertal mice decreases growth and IGF-1 expression in the growth plate. J Endocrinol 177:381-388

44. Altman A, Hochberg Z, Silbermann M 1992 Interactions between growth hormone and dexamethasone in skeletal growth and bone structure of the young mouse. Calcif Tissue Int 51:298-304

45. Silvestrini G, Ballanti P, Patacchioli FR, Mocetti P, Di Grezia R, Wedard BM, Angelucci L, Bonucci E 2000 Evaluation of apoptosis and the glucocorticoid receptor in the cartilage growth plate and metaphyseal bone cells of rats after high-dose treatment with corticosterone. Bone 26:33-42

46. Gafni R, Weise M, Robrecht DT, Meyers JL, Barnes KM, De-Levi S, Baron J 2001 Catch-up growth is associated with delayed senescence of the growth plate in rabbits. Pediatr Res 50:618-623

47. Annefeld M 1992 Changes in rat epiphyseal cartilage after treatment with dexamethasone and glucosaminoglycan-peptide complex. Pathol Res Pract 188:649-652

48. Sanchez CP, He YZ 2002 Alterations in the growth plate cartilage of rats with renal failure receiving corticosteroid therapy. Bone 30:692-698

49. Chrysis D, Ritzen EM, Savendahl L 2003 Growth retardation induced by dexamethasone is associated with increased apoptosis of the growth plate chondrocytes. J Endocrinol 176:331-337

50. Mocetti P, Silvestrini G, Ballanti P, Patacchioli FR, Di Grezia R, Angelucci L, Bonucci E 2001 Bcl-2 and Bax expression in cartilage and bone cells after high-dose corticosterone treatment in rats. Tissue Cell 33:1-7

51. Luo JM, Murphy LJ 1989 Dexamethasone inhibits growth hormone induction of insulin-like growth factor-I (IGF-I) messenger ribonucleic acid (mRNA) in hypophysectomized rats and reduces IGF-I mRNA abundance in the intact rat. Endocrinology 125:165-171

52. Koedam JA, Smink JJ, van Buul-Offers SC 2002 Glucocorticoids inhibit vascular endothelial growth factor expression in growth plate chondrocytes. Mol Cell Endocrinol 29:35-44
53. Abu EO, Horner A, Kusec V, Triffitt JT, Compston JE 2000 The localization of the functional glucocorticoid receptor $\alpha$ in human bone. J Clin Endocrinol Metab $85: 883-889$

54. Baron J, Huang Z, Oerter KE, Bacher JD, Cutler GB Jr 1992 Dexamethasone acts ocally to inhibit longitudinal bone growth in rabbits. Am J Physiol 263:E489-E492

55. Siebler T, Robson H, Shalet SM, Williams GR 2002 Dexamethasone inhibits and thyroid hormone promotes differentiation of mouse chondrogenic ATDC5 cells. Bone 31:457-464

56. Jux C, Leiber K, Hugel U, Blum W, Ohlsson C, Klaus G, Mehls O 1998 Dexamethasone impairs growth hormone $(\mathrm{GH})$-stimulated growth by suppression of local insulin-like growth factor (IGF)-I production and expression of GH-and IGF-Ireceptor in cultured rat chondrocytes. Endocrinology 139:3296-3305

57. Smink JJ, Koedam JA, Koster JG, van Buul-Offers SC 2002 Dexamethasoneinduced growth inhibition of porcine growth plate chondrocytes is accompanied by changes in levels of IGF axis components. J Endocrinol 174:343-352

58. Isaksson OG, Jansson JO, Gause IA 1982 Growth hormone stimulates longitudinal bone growth directly. Science 216:1237-1239

59. Isaksson OG, Lindahl A, Nilsson A, Isgaard J 1987 Mechanism of the stimulatory effect of growth hormone on longitudinal bone growth. Endrocr Rev 8:426-438

60. Barnard R, Haynes KM, Werther GA, Waters MJ 1988 The ontogeny of growth hormone receptors in the rabbit tibia. Endocrinology 122:2562-2569

61. Gevers EF, van der Eerden BC, Karperien M, Raap AK, Robinson IC, Wit JM 2002 Localization and regulation of the growth hormone receptor and growth hormonebinding protein in the rat growth plate. J Bone Miner Res 17:1408-1419

62. Werther GA, Haynes K, Edmonson S, Oakes S, Buchanan CJ, Herington AC, Waters MJ 1993 Identification of growth hormone receptors on human growth plate chondrocytes. Acta Paediatr Suppl 82; 391:50-53

63. Wang J, Zhou J, Cheng CM, Kopchick JJ, Bondy CA 2004 Evidence supporting dual, IGF-I-independent and IGF-I-dependent, roles for GH in promoting longitudinal bone growth. J Endocrinol 180:247-255

64. Wang J, Zhou J, Bondy CA 1999 Igf1 promotes longitudinal bone growth by insulin-like actions augmenting chondrocyte hypertrophy. FASEB J 13:1985-1990

65. Hunziker EB, Wagner J, Zapf J 1994 Differential effects of insulin-like growth factor I and growth hormone on developmental stages of rat growth plate chondrocytes in vivo. J Clin Invest 93:1078-1086

66. Laursen EM, Lanng S, Rasmussen MH, Koch C, Skakkebaek NE, Muller J 1999 Normal spontaneous and stimulated GH levels despite increased IGF-I concentrations in cystic fibrosis patients. Eur J Endocrinol 140:315-321

67. Ozen M, Cokugras H, Ozen N, Camcioglu Y, Akcakaya N 2004 Relation between serum Insulin-like growth factor-I and insulin-like growth factor-binding protein-3 levels, clinical status and growth parameters in prepubertal cystic fibrosis patients. Pediatr Int 46:429-435

68. Ballinger A 2002 Fundamental mechanisms of growth failure in inflammatory bowel disease. Horm Res 58:7-10

69. Gronbek H, Thogersen T, Frystyk J, Vilstrup H, Flyvbjerg A, Dahlerup JF 2002 Low free and total insulinlike growth factor I (IGF-I) and IGF binding protein-3 levels in chronic inflammatory bowel disease: partial normalization during prednisolone treatment. Am J Gastroenterol 97:673-678

70. Tsatsoulis A, Siamopoulou A, Petsoukis C, Challa A, Bairaktari E, Seferiadis K 1999 Study of growth hormone secretion and action in growth-retarded children with juvenile chronic arthritis. Growth Horm IGF Res 9:143-149

71. Tonshoff B, Veldhuis JD, Heinrich U, Mehls O 1995 Deconvolution analysis of spontaneous nocturnal growth hormone secretion in prepubertal children with chronic renal failure. Pediatr Res 37:86-93

72. Schaefer F, Veldhuis JD, Jones J, Scharer K 1994 Alterations in growth hormone secretion and clearance in peripubertal boys with chronic renal failure and after renal transplantation. Cooperative Study Group of Pubertal Developmental in Chronic Renal Failure. J Clin Endocrinol Metab 78:1298-1306

73. Tonshoff B, Eden S, Weiser E, Carlsson B, Robinson IC, Blum WF, Mehls O 1994 Reduced hepatic growth hormone $(\mathrm{GH})$ receptor gene expression and increased plasma GH binding protein in experimental uremia. Kidney Int 45:1085-1092

74. Tonshoff B, Cronin MJ, Reichert M, Haffner D, Wingen AM, Blum WF, Mehls O 1997 Reduced concentration of serum growth hormone (GH)-binding protein in children with chronic renal failure: correlation with GH insensitivity. The European Study Group for Nutritional Treatment of Chronic Renal Failure in Childhood. The German Study Group for Growth Hormone Treatment in Chronic Renal Failure. J Clin Endocrinol Metab 82:1007-1013

75. Chan W, Valerie KC, Chan JC 1993 Expression of insulin-like growth factor-1 in uremic rats: growth hormone resistance and nutritional intake. Kidney Int 43:790-795

76. Tonshoff B, Blum W, Wingen AM, Mehls O 1995 Seruminsulin-like growth factors (IGFs) and IGF binding proteins 1,2 , and 3 in children with chronic renal failure: relationship to height and glomerular filtration rate. J Clin Endocrinol Metab 80:2684-2691

77. Tonshoff B, Blum W, Mehls O 1996 Seruminsulin-like growth factors and their binding proteins in children with end-stage renal disease. Pediatr Nephrol 10:269-274

78. Powell DR, Liu F, Baker BK, Hintz RL, Durham SK, Brewer ED, Frane JW, Tonshoff B, Mehls O, Wingen AM, Watkins SL, Hogg RJ, Le PD 1997 Insulin-like growth factor binding protein- 6 are levated in serum of children with chronic renal failure: a report of the Southwest Pediatric Nephrology Study Group. J Clin Endocrinol Metab 82:2978-2984

79. Ulinski T, Mohan S, Kiepe D, Blum W, Wingen AM, Mehls O, Tonshoff B 2000 Serum insulin-like growth factor binding protein (IGFBP)-4 and IGFBP-5 in children with chronic renal failure: relationship to growth and glomerular filtration rate. The European Study Group for Nutritional Treatment of Chronic Renal Failure in Childhood. German Study Group for Growth Hormone Treatment in Chronic Renal Failure. Pediatr Nephrol 14:589-597 